\title{
THE SOCIOLOGY OF LAW AND THE GLOBAL TRANSFORMATION OF DEMOCRACY
}

This book provides a new legal-sociological account of contemporary democracy. This is based on a revision of standard positions in democratic theory, reflecting the impact of global legal norms on the institutions of national states. Chris Thornhill argues that the establishment of fully democratic, fully inclusive governance systems in national societies was generally impeded by inner-societal structural factors, and that inclusive patterns of democratic citizenship only evolved on the foundation of global legal norms that were consolidated after 1945. He claims that this process can be best understood through a transposition of key insights of classical legal sociology onto the form of global society. Extensive analysis of select case studies in different regions illustrate these claims. Thornhill offers a sociological theory of global law to explain contemporary processes of democratic integration and institutional formation and contemporary constructions of citizenship and political rights. This title is also available as Open Access.

CHRIS THORNHILL is Professor in Law at the University of Manchester. $\mathrm{He}$ is the author of several books on the sociology of law, especially on the sociology of constitutions. His books and other writings have been translated into many languages. He is a member of the Academia Europaea. 


\section{GLOBAL LAW SERIES}

The series provides unique perspectives on the way globalization is radically altering the study, discipline and practice of law. Featuring innovative books in this growing field, the series explores those bodies of law which are becoming global in their application, and the newly emerging interdependency and interaction of different legal systems. It covers all major branches of the law and includes work on legal theory, history, and the methodology of legal practice and jurisprudence under conditions of globalization. Offering a major platform on global law, these books provide essential reading for students and scholars of comparative, international and transnational law.

\section{Series Editors}

M.E.A Goodwin Tilburg University

Randall Lesaffer Tilburg University

David Nelken King's College London

Han Somsen Tilburg University

Books in the Series

Intimations of Global Law Neil Walker

Legalized Families in the Era of Bordered Globalization Daphna Hacker

Transnational Sustainability Laws Phillip Paiement

The Sociology of Law and the Global Transformation of Democracy Chris Thornhill

Authority and the Globalisation of Inclusion and Exclusion Hans Lindahl 


\section{THE SOCIOLOGY OF LAW AND THE GLOBAL TRANSFORMATION OF DEMOCRACY}

CHRIS THORNHILL

University of Manchester 


\section{CAMBRIDGE UNIVERSITY PRESS}

University Printing House, Cambridge CB2 8BS, United Kingdom

One Liberty Plaza, 20th Floor, New York, NY 10006, USA

477 Williamstown Road, Port Melbourne, VIC 3207, Australia

314-321, 3rd Floor, Plot 3, Splendor Forum, Jasola District Centre, New Delhi - 110025, India

79 Anson Road, \#06-04/06, Singapore 079906

Cambridge University Press is part of the University of Cambridge.

It furthers the University's mission by disseminating knowledge in the pursuit of education, learning, and research at the highest international levels of excellence.

www.cambridge.org

Information on this title: www.cambridge.org/9781107199903

DOI: $10.1017 / 9781108186049$

(c) Chris Thornhill, 2018

This work is in copyright. It is subject to statutory exceptions and to the provisions of relevant licensing agreements; with the exception of the Creative Commons version the link for which is provided below, no reproduction of any part of this work may take place without the written permission of Cambridge University Press.

An online version of this work is published under a Creative Commons Open Access license CC-BY-NC-ND 4.0 which permits re-use, distribution and reproduction in any medium for non-commercial purposes providing appropriate credit to the original work is given. You may not distribute derivative works without permission. To view a copy of this license, visit https://creativecommons.org/licenses/by-nc-nd/4.0

All versions of this work may contain content reproduced under license from third parties.

Permission to reproduce this third-party content must be obtained from these third-parties directly.

When citing this work, please include a reference to the DOI 10.1017/9781108186049

First published 2018

Printed in the United Kingdom by Clays, St Ives plc

A catalogue record for this publication is available from the British Library.

Library of Congress Cataloging-in-Publication Data

Names: Thornhill, C. J. (Christopher J.), 1966- author.

Title: The sociology of law and the global transformation of democracy /

Chris Thornhill, University of Manchester.

Description: Cambridge, United Kingdom ; New York, NY, USA : Cambridge

University Press, 2018. | Series: Global law series | Includes

bibliographical references and index.

Identifiers: LCCN 2018009340| ISBN 9781107199903 (hardback) | ISBN 9781316649060 (paperback)

Subjects: LCSH: Sociological jurisprudence. | Law-Political aspects. | Democracy-Social aspects.

Classification: LCC K370 .T545 2018 | DDC 340/.115-dc23 LC record available at https://lccn.loc.gov/2018009340

ISBN 978-1-107-19990-3 Hardback

ISBN 978-1-316-64906-0 Paperback

Cambridge University Press has no responsibility for the persistence or accuracy of URLs for external or third-party internet websites referred to in this publication and does not guarantee that any content on such websites is, or will remain, accurate or appropriate. 